\title{
Colletotrichum lindemuthianum Races Prevalent on Dry Beans in North Dakota and Potential Sources of Resistance
}

Rubella S. Goswami, Luis E. del Rio-Mendoza, and Robin S. Lamppa, Department of Plant Pathology, North Dakota State University, Fargo 58108-6050; and Jeff Prischmann, North Dakota State Seed Department, Fargo 58108

\begin{abstract}
Goswami, R. S., del Rio-Mendoza, L. E., Lamppa, R. S., and Prischmann, J. 2011. Colletotrichum lindemuthianum races prevalent on dry beans in North Dakota and potential sources of resistance. Plant Dis. 95:408-412.

Anthracnose caused by Colletotrichum lindemuthianum is one of the most important diseases of dry edible beans in the major production areas worldwide. This pathogen is highly variable, with numerous races. Disease management relies heavily on genetic resistance and use of clean seed. Genetic resistance is controlled by major resistance genes conferring protection against specific races of the pathogen. Therefore, knowledge of the pathogen population in a region is essential for effective screening of germplasm. Surveys were conducted for more than 6 years in North Dakota, the largest dry-bean-growing state

in the United States, and seed samples submitted for certification were assessed to identify the $C$. lindemuthianum races prevalent in the region. A collection of commercial cultivars from different market classes of dry bean was also screened for resistance to these races. Disease incidence was found to be low in most years. However, in addition to the previously reported races of anthracnose 7,73 , and 89, two new races, 1153 and 1161, previously never reported in the United States, were identified and the commercial cvs. Montcalm, Avalanche, Vista, and Sedona where found to possess resistance to these races.
\end{abstract}

Anthracnose, caused by Colletotrichum lindemuthianum (Sacc. \& Magnus) Briosi \& Cavara, a seedborne fungal pathogen, is one of the most important diseases of common bean (Phaseolus vulgaris L.). The disease affects all aerial parts of the plant. Symptoms commonly observed include angular to linear dark-brown, black, or reddish lesions that initially appear on the underside of the leaves and eventually become visible on the upper surface as disease progresses. Similar lesions may be observed on the stem and petiole as well. The small, round cankers with a dark border and sunken center on the pods are often the most prominent symptoms visible under field conditions (22). Anthracnose is prevalent in a majority of the bean-growing areas of the world but is of particular importance in the subtropical and temperate regions (1). Relatively cool and humid conditions favor disease development (14) and could result in complete crop failure (20). C. lindemuthianum is a highly variable pathogen with a large number of races (13). The disease is primarily controlled by use of clean seed, application of fungicides, and use of resistant cultivars (3), with the latter being the most common practice.

Host resistance is believed to be controlled by a gene-for-gene interaction (9). Thirteen major resistance genes, designated by the abbreviation " $\mathrm{Co}$ " followed by a number, have been identified to date $(10,11,13)$. P. vulgaris was introduced from Mesoamerican and Andean centers of origin (15) and, among the known $C$. lindemuthianum resistance genes, $\mathrm{Co}-2$ to $\mathrm{Co}-10$ are of Middle American origin while $\mathrm{Co}-1$ and $\mathrm{Co}-11$ to $\mathrm{Co}-13$ are of Andean origin (13). The races of $C$. lindemuthianum are determined based on the reaction of the isolates to a standard set of 12 differential cultivars $(1,19)$.

The efficient use of genetic resistance in dry bean cultivars grown in the United States resulted in a decline in the incidence of this disease (14). However, the appearance or accidental introduction of new races that could overcome the available resistance em-

Corresponding author: R. S. Goswami,

E-mail: Rubella.Goswami@ndsu.edu

Accepted for publication 29 October 2010.

doi:10.1094/PDIS-06-10-0429

(C) 2011 The American Phytopathological Society phasizes the need for an efficient monitoring system and adequate knowledge about pathogen populations (5). According to previous studies, races 89 and 7 were reported to have been disseminated in seed from Michigan in 1991 (21) and were detected in North Dakota in 1994 (12). Later, race 73, which had been found in Michigan, was also detected in North Dakota (5), where this race is considered to be the most prevalent. While cultivars are currently screened for resistance to anthracnose, systematic efforts to identify the races present in North Dakota, the largest dry-bean-growing state in the United States, which accounts for nearly $40 \%$ of the country's dry bean hectarage (United States Department of Agriculture-National Agricultural Statistics Service), have been limited. Considering the fact that genetic resistance is the primary method for controlling this disease and that, recently, a new race, named race 105, was detected in Manitoba, Canada, a province neighboring North Dakota (7), it is essential to assess the races present and screen for resistance using isolates representing the races prevalent in the region. Therefore, the goal of this study was to assess the prevalence of anthracnose in the dry-bean-growing areas of North Dakota and to determine the races of the pathogen present in this state. Additionally, we evaluated commercial dry bean cultivars belonging to different market classes grown in the region for resistance to the currently existing and newly found races that could serve as sources of resistance to this pathogen.

\section{Materials and Methods}

Survey and sampling. A foliar disease survey was conducted for 6 years between 2003 and 2009. The activities included scouting and sampling of fields in four of the five major dry-bean-growing counties in North Dakota: Pembina, Walsh, Grand Forks, Traill, and Steele. In the years 2003, 2004, and 2005, the samples were collected between late August and early September when the crop was in mid- to late pod-filling (R4 to R6); whereas, in 2007, 2008, and 2009, the sampling was done in early August when the crop was at the mid- to full flowering and early pod-filling stages (R2 to R4). The number of fields sampled each year, disease incidence, and races of the isolates obtained are listed in Table 1. In 2003 to 2005, visual disease assessments were conducted at 10 sites selected along a zigzag pattern with at least $10 \mathrm{~m}$ between sites in each field. Thereafter, the survey pattern was modified and assessments were conducted at five locations along a $\mathrm{W}$ transect within each field. At each site, disease incidence was noted for 20 
plants, resulting in a total of 200 plants examined per field in 20032005 and 100 plants per field in 2007 to 2009.

In addition to samples collected through the survey from 2003 to 2009, Canadian seed lots submitted to the North Dakota State Seed Laboratory (NDSSD) for certification were also evaluated in 2001 and 2002. Symptomatic plants collected by crop consultants in the region from growers' fields and some seed samples submitted for testing to the NDSSD were also incorporated in the evaluation in 2005 and 2007, respectively.

Pathogen isolation and inoculum preparation. Survey samples brought back to the laboratory and symptomatic seed from the seed lots were surface disinfested using a 1-min soak in $10 \%$ commercial bleach followed by three rinses in sterile distilled water, then plated on half-strength acidified potato dextrose agar (PDA) for initial isolation of the pathogens (6). Pure cultures of these pathogens were established by single-spore isolation and identified using standard microbiological procedures such as morphological characteristics, growth on selective media, and fruiting structures. In certain cases, the surface-disinfested leaf section was placed on a sterile filter paper in a petri dish and incubated for $24 \mathrm{~h}$ at $21^{\circ} \mathrm{C}$, following which a sterile cotton swab was used to touch the surface of the lesion and streak a PDA plate or Mathur's medium containing glucose $(2.8 \mathrm{~g}), \mathrm{MgSO}_{4} \cdot 7 \mathrm{H}_{2} \mathrm{O}(1.23 \mathrm{~g})$, neopeptone $(2.0 \mathrm{~g})$, $\mathrm{KH}_{2} \mathrm{PO}_{4}(2.72 \mathrm{~g})$, and agar $(15.0 \mathrm{~g})$ in 1 liter of distilled water (17). Single, isolated colonies where picked within $48 \mathrm{~h}$ from streaking.

Seed samples were evaluated by the NDSSD according to their standard protocol as mentioned in their website, http://www.nd. gov/seed/diagnosticlab/beananthracnose.aspx. The protocol involved a grow-out test where seedlings from 1,000 seed were evaluated for a period of 14 days for the presence or absence of $C$. lindemuthianum. Symptomatic seedlings were occasionally sent for further confirmation and race typing.

The isolates collected and reference cultures of races 7, 73, and 89 obtained from J. Kelly (Michigan State University) were grown on Mathur's medium (17) for 7 to 14 days at $25^{\circ} \mathrm{C}$ under dark conditions for sporulation. Inoculum was prepared by washing spores off the surface of the agar with $0.01 \%$ Tween 80 in distilled water and a cotton swab. The suspension was filtered through cheese cloth and adjusted to $1 \times 10^{6}$ spores $/ \mathrm{ml}$ using a hemacytometer (5). Race 73 was used as a positive control in the determination of the race of the isolate.

Race identification and resistance evaluation. Five germinated seed from 12 commercial dry bean cultivars-namely, Othello (pinto), Navigator (navy), Norstar (navy), Lariat (pinto), Matterhorn (great northern), Stampede (pinto), T-39 (black), Sedona (pink), Maverick (pinto), Vista (navy), Avalanche (navy), and Montcalm (dark red kidney) — and a set of 12 standard differentials $(18,19)$ were grown in flats containing Sunshine Soil Mix no. 1 (Sun-Gro Horticulture, Canada) until primary leaf expansion. Spore suspension was sprayed on the underside of fully expanded primary leaves until runoff with a Paasche airbrush using $137 \mathrm{kPa}$. The inoculated plants were placed in a humidity chamber $(100 \%$ relative humidity) with a 14-h light period for 5 days, then returned to the greenhouse. At 10 days post inoculation, the differentials were rated for their reaction to inoculation. Susceptibility was determined by the presence of sporulating lesions on the inoculated differentials. Absence of visible lesions or the presence of nonsporulating small lesions was considered to be a resistant reaction. The severity of the disease on the commercial cultivars was rated 10 days after inoculation using a 0-to-9 scale where each unit represented a $10 \%$ increment in dead plant tissue (5). The race determination and cultivar inoculations were repeated three times and the entire trial was conducted twice.

Statistical analysis. Statistical analyses and data transformation were conducted using the Statistical Analysis System package (version 9.2; SAS Institute, Inc., Cary, NC). Disease severity values were transformed into percentages of affected tissues by taking the midpoint of the range of values represented by each unit in the scale; in this way, a 0 in the scale, which represented values ranging from 0 to $9 \%$, has $4.5 \%$ as its midpoint. Analysis of variance using a randomized complete block design was first performed on data from each trial separately. Once the homogeneity of variance test conducted using the modified Levene's test (Brown and Forsythe test option from SAS) indicated that the variances of both trials were homogeneous, the trials were combined. When the combined analysis confirmed that there were no statistical differences between trials and no significant trial-replication interaction, the data were merged and analyzed as a randomized complete block design. Treatment means were separated using Fisher's protected least significant difference test and single-degree-of-freedom contrast analyses were conducted to discriminate between market classes and between specific cultivars within market classes.

\section{Results}

Anthracnose prevalence. During the 6 years of this study, 387 fields were scouted for the presence of anthracnose but only 5 of them yielded positive samples, a $1.3 \%$ overall prevalence (Table 1). Anthracnose was detected only in 2003 and 2005. In 2003, only 1 of 90 scouted fields was found to be heavily infested by anthracnose, with an incidence estimated at 50\%; no other fields had symptomatic plants detected. In 2005, the year with the highest anthracnose prevalence, the disease was detected in almost $8 \%$ of fields scouted, and the incidence there ranged between 10 and $27 \%$. These fields were planted to either black or pinto bean and were located in Walsh County in northeastern North Dakota. In total, 11 anthracnose isolates were retrieved from infected samples in these 2 years.

The majority of the seed samples $(70 \%)$ tested by the NDSSD were pinto bean; the rest consisted of $12 \%$ pink, $9 \%$ navy, $6 \%$ black, and 3\% small red bean. Of the 884 seed samples evaluated for the presence of seedborne anthracnose between 2001 and 2009, 34 samples yielded positive results for anthracnose, a 3.8\% prevalence. The number of samples evaluated by the NDSSD each year over the period of the study and the results are mentioned in Table 2.

C. lindemuthianum isolations and race typing. Of the 29 isolates retrieved from infected plant tissues during the survey, seed and pods submitted by crop consultants from fields in North Dakota, and seed samples from the NDSSD, $89.6 \%$ belonged to race 73 and $3.4 \%$ each to the races 89, 1153, and 1161 (Tables 1 and 2). Isolates from races 73, 89, and 1153 were retrieved from grower fields across the state whereas race 1161 was detected in a seed lot from Manitoba, Canada. The typical reaction of the differentials to isolates of these anthracnose races is listed in Table 3.

Reactions of commercial cultivars to five races of $C$. lindemuthianum. Significant differences between commercial cultivars as well as statistically significant interactions between cultivars and C. lindemuthianum races were observed in this study (Fig. 1A to

Table 1. Fields surveyed in North Dakota for foliar disease along with incidence of anthracnose and the races identified from them ${ }^{\mathrm{a}}$

\begin{tabular}{|c|c|c|c|c|c|}
\hline Year & No. of fields sampled & No. of fields with anthracnose & Mean incidence $(\%)$ & No. of isolates obtained & Races identified \\
\hline 2003 & 90 & 1 & 50 & 3 & 73 \\
\hline 2004 & 108 & 0 & - & - & - \\
\hline 2005 & 50 & 4 & 19 & 8 & $73,89,1153$ \\
\hline 2007 & 55 & 0 & - & - & - \\
\hline 2008 & 39 & 0 & - & - & - \\
\hline 2009 & 45 & 0 & - & - & - \\
\hline
\end{tabular}

a Symbol: “-” indicates no samples evaluated. 
E). Most cultivars were resistant to race 7, with the exception of Montcalm, a red kidney bean (Fig. 1A). The most virulent isolates belonged to races 73 and 89 which caused susceptible reactions in 10 and 9 of the 12 cultivars evaluated, respectively (Fig. 1B and C). Race 73 was particularly virulent on navy bean, although three of the pinto bean cultivars were also susceptible to this race. Conversely, race 89 was particularly virulent on pinto bean, although two of the four navy bean cultivars were also susceptible to it. Races 1153 and 1161 showed identical virulence profile on all cultivars evaluated (Fig. 1D and E). These races were more virulent on pinto bean, affecting three of the four cultivars evaluated, than on navy bean. Pink bean cv. Sedona, kidney bean Montcalm, and navy bean cvs. Avalanche and Vista were resistant to these two races. The only black bean cultivar evaluated, T-39, was resistant to race 7 , susceptible to races 73 and 89 , and had intermediate reaction against races 1153 and 1161 .

Considering that pinto and navy bean are more common in North Dakota, comparisons were conducted between these two groups, each of which was represented by four cultivars. Pinto and navy bean cultivars, as market classes, reacted in statistically similar way to inoculation with races 73,1153 , and 1161 .

However, differences were observed in reactions to races 7 and 89. At least one cultivar with partial resistance to each race was found to be present in both pinto and navy bean. Interestingly, the navy bean cvs. Avalanche and Vista appeared to be resistant to all races but race 73 . Resistance to race 73 was present only in the kidney bean cv. Montcalm.

\section{Discussion}

The low incidence of anthracnose and its sporadic appearance observed over 6 years of disease surveys demonstrates the success of the implementation of management strategies suggested by del Rio et al. (5) to control this disease in the north-central United
States. Seed testing for anthracnose was started by the NDSSD in 2001. Among the seed lots sent for isolation of $C$. lindemuthianum, the majority of the isolates were found to belong to race 73. However, in 2002, a seed lot of pink bean from Manitoba, Canada was found to be infected with race 1161 of $C$. lindemuthianum based on evaluations of monosporic cultures using the dry bean anthracnose differentials (4). This race had been previously reported in Costa Rica (16) but never in the United States.

Anthracnose incidence was low in 2003 and 2004 and the isolates obtained from surveys were all found to belong to race 73 . In 2005, however, anthracnose was reported from four fields planted to black and pinto bean around the Grafton area in Walsh County. Samples from pinto and navy bean crops suspected to be infected with anthracnose were also submitted by crop consultants from the state for testing. Tests revealed that one of these samples, a pinto bean, was infected by $C$. lindemuthianum race 89 and another, a navy bean, by race 1153 . The rest of the infected samples were contaminated with race 73 . As in the case of race 1161 , race 1153 has been reported from Costa Rica and Ecuador but not from the United States (16). In 2007, anthracnose-like symptoms were observed on the stems of nearly mature plants from 15 fields during the disease survey but the isolates obtained were morphologically similar to $C$. truncatum. These were seen sporulating on the infected bean leaves when placed in a humid chamber but did not produce lesions upon inoculation of dry bean plants. Apart from these, three infected seed samples obtained from the NDSSD were found to be infected with race 73. In 2008 and 2009, anthracnose was not found in any of the fields surveyed in North Dakota.

Overall, the evaluation of 29 isolates collected from infected seed sources and growers' fields showed that race 73 is currently the most prevalent race of $C$. lindemuthianum in this region. However, there seems to be very little resistance to this race among the set of cultivars used in this study. All cultivars of the different mar-

Table 2. Seed samples tested for the presence of Colletotrichum lindemuthianum and the races identified from them ${ }^{\mathrm{a}}$

\begin{tabular}{|c|c|c|c|c|c|c|}
\hline \multirow[b]{2}{*}{ Year } & \multicolumn{2}{|c|}{ No. of samples evaluated for anthracnose } & \multirow[b]{2}{*}{ Infection $(\%)^{\mathbf{b}}$} & \multicolumn{2}{|c|}{ Anthracnose isolates } & \multirow[b]{2}{*}{ Class $^{\mathrm{c}}$} \\
\hline & Positive & Negative & & Retrieved & Race ID & \\
\hline 2001 & 6 & 118 & $0.1-0.4$ & 4 & 73 & Pinto; Navy \\
\hline 2002 & 7 & 87 & $0.1-2.3$ & 6 & 73,1161 & Pinto; Navy (73); Pink (1161) \\
\hline 2003 & 0 & 92 & 0 & 3 & 73 & Pinto \\
\hline 2004 & 5 & 69 & $0.1-0.3$ & 1 & 73 & Small red kidney \\
\hline 2005 & 10 & 89 & $0.1-0.8$ & 2 & 73 & Black \\
\hline 2006 & 0 & 107 & 0 & - & - & - \\
\hline 2007 & 6 & 100 & $0.1-0.7$ & 3 & 73 & Pinto \\
\hline 2008 & 0 & 87 & 0 & - & - & - \\
\hline 2009 & 0 & 101 & 0 & - & - & - \\
\hline
\end{tabular}

a Symbol: “_" indicates no samples evaluated.

${ }^{\mathrm{b}}$ Range of seed infection.

${ }^{\mathrm{c}}$ Anthracnose-positive market class.

Table 3. Reactions of isolates for the different anthracnose races detected in this region to the set of 12 differential cultivars ${ }^{\mathrm{a}}$

\begin{tabular}{|c|c|c|c|c|c|c|c|}
\hline \multirow[b]{2}{*}{ Race differential } & \multirow[b]{2}{*}{ Binary no. } & \multirow[b]{2}{*}{ Resistance genes } & \multicolumn{5}{|c|}{ Races $^{b}$} \\
\hline & & & 7 & 73 & 89 & 1153 & 1161 \\
\hline Michelite & 1 & Co-11 & $\mathrm{S}$ & $\mathrm{S}$ & $\mathrm{S}$ & $\mathrm{S}$ & $\mathrm{S}$ \\
\hline MDRK & 2 & Co- 1 & $\mathrm{~S}$ & $\mathrm{R}$ & $\mathrm{R}$ & $\mathrm{R}$ & $\mathrm{R}$ \\
\hline Perry Marrow & 4 & $\mathrm{Co}-1^{3}$ & $\mathrm{~S}$ & $\mathrm{R}$ & $\mathrm{R}$ & $\mathrm{R}$ & $\mathrm{R}$ \\
\hline Cornell 49242 & 8 & Co-2 & $\mathrm{R}$ & $\mathrm{S}$ & $\mathrm{S}$ & $\mathrm{R}$ & $\mathrm{S}$ \\
\hline Widusa & 16 & $\mathrm{Co}-1^{5}, \mathrm{Co}-3^{3}$ & $\mathrm{R}$ & $\mathrm{R}$ & $\mathrm{S}$ & $\mathrm{R}$ & $\mathrm{R}$ \\
\hline Kaboon & 32 & $\mathrm{Co}-1^{2}$ & $\mathrm{R}$ & $\mathrm{R}$ & $\mathrm{R}$ & $\mathrm{R}$ & $\mathrm{R}$ \\
\hline Mexico 222 & 64 & $\mathrm{Co}-3$ & $\mathrm{R}$ & $\mathrm{S}$ & $\mathrm{S}$ & $\mathrm{R}$ & $\mathrm{R}$ \\
\hline PI 207262 & 128 & $\mathrm{Co}-4^{3}, \mathrm{Co}-3^{3}$ & $\mathrm{R}$ & $\mathrm{R}$ & $\mathrm{R}$ & $\mathrm{S}$ & $\mathrm{S}$ \\
\hline TO & 256 & Co-4 & $\mathrm{R}$ & $\mathrm{R}$ & $\mathrm{R}$ & $\mathrm{R}$ & $\mathrm{R}$ \\
\hline TU & 512 & Co- 5 & $\mathrm{R}$ & $\mathrm{R}$ & $\mathrm{R}$ & $\mathrm{R}$ & $\mathrm{R}$ \\
\hline AB 136 & 1,024 & Сo-6, Сo-8 & $\mathrm{R}$ & $\mathrm{R}$ & $\mathrm{R}$ & $\mathrm{S}$ & $\mathrm{S}$ \\
\hline G 2333 & 2,048 & $\mathrm{Co}-4^{2}, \mathrm{Co}-5, \mathrm{Co}-7$ & $\mathrm{R}$ & $\mathrm{R}$ & $\mathrm{R}$ & $\mathrm{R}$ & $\mathrm{R}$ \\
\hline
\end{tabular}

${ }^{a}$ Binary numbers and resistance genes present are according to Dongfang et al. (7), Kelly and Vallejo (13), and the gene list posted on the website for the Bean Improvement Cooperative (http://www.css.msu.edu/bic/PDF/Bean_Genes_List_2010.pdf).

${ }^{\mathrm{b}} \mathrm{R}=$ resistant and $\mathrm{S}=$ susceptible. 
ket classes except the kidney bean Montcalm appeared to be fairly susceptible to this race. This supports the notion that the reduction in the incidence of anthracnose in the region is likely to be due to other management techniques rather than to genetic resistance which, on its own, would not have been able to keep disease levels so low in the presence of race 73. Anthracnose is known to be largely seed transmitted and the use of disease-free seed is considered to be the other cornerstone strategy, apart from genetic resistance, in controlling this disease. The importance of using diseasefree seed is further strengthened by the discovery of race 1161 in the pink bean seed sample being imported into the country. Moreover, samples submitted to the NDSSD for certification found to be infected with anthracnose were denied entry into the region for planting, thereby keeping the pathogen at bay. Seed testing and certification is one of the major methods for restricting the spread of the disease but the practice of pooling seed from different fields and sampling from the pooled seed lot for testing, a practice often referred to by the seed testing authorities, could affect the chances of detecting $C$. lindemuthianum. This is often evident in the low percentage of infected seed detected in each of the seed lots tested. Therefore, scouting fields in dry-bean-growing areas in addition to seed testing should be encouraged.

The isolation of the new races 1153 and 1161 that overcome the resistance genes available in most of the common dry bean cultivars highlights the need for constant vigilance required to sustain low disease. Cvs. Avalanche, Montcalm, Sedona, and Vista showed
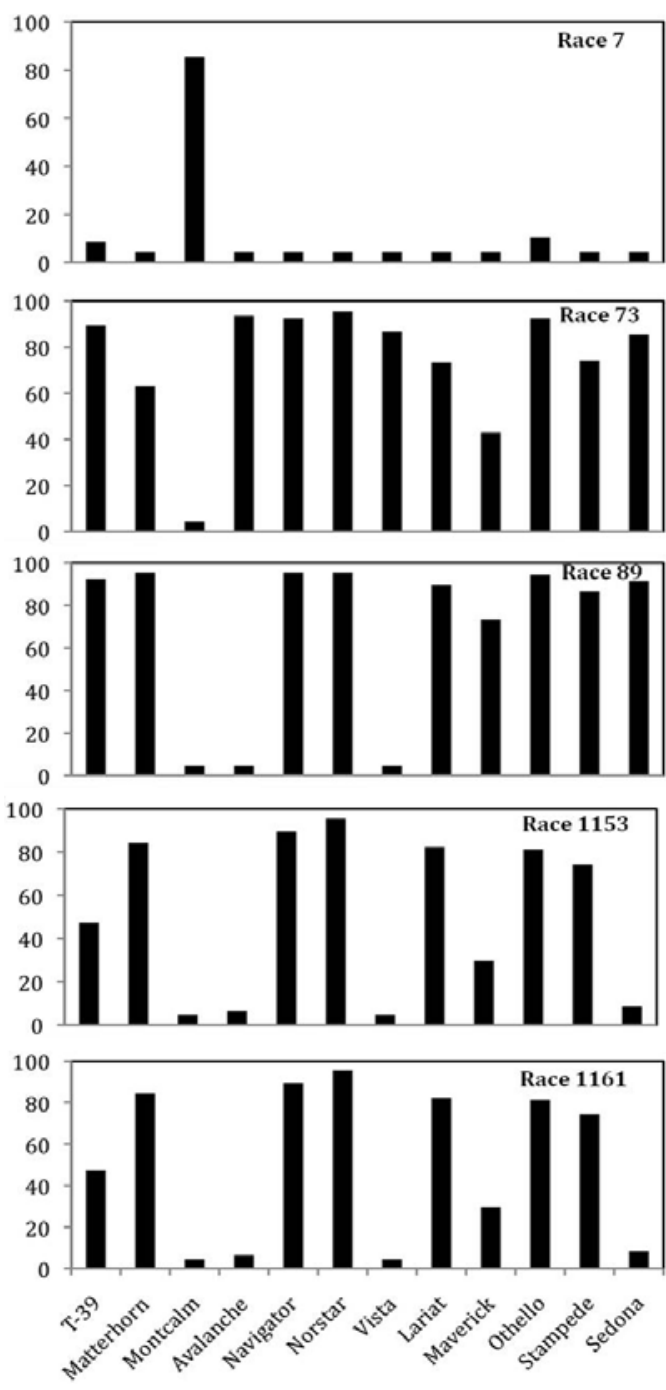

Fig. 1. Disease severity caused by isolates of the different races on the dry bean cultivars. The $\mathrm{X}$-axis shows the cultivars used in the study and the $\mathrm{Y}$-axis depicts mean disease severity due to infection by each race. some resistance to these new races but they are susceptible to either race 73 or race 7 . On the other hand, cvs. Maverick, Lariat, Othello, and Matterhorn showed large variations in their reactions to races 1153 and 1161. These were observed in the differences in disease severity among the inoculated plants of each cultivar and also reflected in the standard deviations calculated from the replicates of disease evaluations. The deviations suggest that these four cultivars could be segregating for resistance to the new races. Reactions of the cultivars evaluated to the different races (Fig. 1) when compared with the differential reactions (Table 3) suggest that genes $\mathrm{Co}-3$ and $\mathrm{Co}-1$ as well as allele $\mathrm{Co}^{3} \mathrm{I}^{3}$ could potentially be contributing toward resistance to the new races in these commercial cultivars; however, this needs to be studied further. However, commercial cultivars from this study possessing genes $\mathrm{Co}-3$ and $C o-1$ as well as allele $C o-I^{3}$ could also be used as parental lines to speed up the release of materials resistant to the new races; however, it would be preferable to use these genes in combination with genes such as $\mathrm{Co}-4$ and $\mathrm{Co}-5$ that provide resistance to all the prevalent races and are likely to give a more stable protection against this pathogen.

It has been suggested that races originally isolated from the Andean cultivars are more aggressive on cultivars from the Andean gene pool than Meso-American cultivars $(2,8)$. The set used in this study is limited in the representation of cultivars from the Andean gene pool but the findings show that the two races 1153 and 1161, originally characterized from Ecuador and Costa Rica, are highly aggressive on commercial cultivars from the Meso-American gene pool. Differential cvs. MDRK, Perry Marrow, and Kaboon from the Andean gene pool could, however, serve as potential sources of resistance to these races. Though differential cultivars are considered to be potential sources of resistance, their use is often associated with difficulties such as photoperiod sensitivity and undesirable agronomic characteristics. These difficulties could be reduced or avoided with the use of commercial cultivars such as the ones identified in this study. The known lineage and improved agronomic traits along with a number of preintegrated resistance genes makes the use of cultivars such as Avalanche, Montcalm, Sedona, and Vista as potential sources of resistance significantly easier and reduces the time required in the integration process. Among these, Montcalm possesses resistance to all the races evaluated in this study except race 7, whereas Avalanche, Vista, and Sedona appear to have resistance to races $7,89,1153$, and 1161 .

In summary, our findings confirm that race 73 continues to be the most prevalent race of $C$. lindemuthianum associated with anthracnose of dry bean in North Dakota. However, other races, including 7, 89, 1153, and 1161, have been detected in the region. Among these, 1153 and 1161 were reported for the first time in North America. Isolates from all these races are capable of infecting dry bean cultivars of the different market classes grown in the region with varying degrees of disease severity. The anthracnose resistance genes $\mathrm{Co}-3$ and $\mathrm{Co}-1$ and the allele $\mathrm{Co}-\mathrm{I}^{3}$ are likely to confer resistance to the races 1153 and 1161 in some of the cultivars evaluated in this study. Sources of resistance to all these races exist among the currently cultivated cultivars from different market classes that can be included in gene pyramids while breeding dry bean lines for this region.

\section{Acknowledgments}

Funding for this research was provided by Northarvest Bean Seed Growers Association. We thank J. Kelly from Michigan State University for providing the control isolates of $C$. lindemuthianum and seed for differentials.

\section{Literature Cited}

1. Balardin, R. S., Jarosz, A. M., and Kelly, J. D. 1997. Virulence and molecular diversity in Colletotrichum lindemuthianum from South, Central, and North America. Phytopathology 87:1184-1191.

2. Balardin, R. S., and Kelly, J. D. 1998. Interaction between Colletotrichum lindemuthianum races and gene pool diversity in Phaseolus vulgaris. J. Am. Soc. Hortic. Sci. 123:1038-1047.

3. Davide, L. M. C., and de Souza, E. A. 2009. Pathogenic variability within race 65 of Colletotrichum lindemuthianum and its implications for common bean breeding. Crop Breed. Appl. Biotechnol. 9:23-30. 
4. del Rio, L. E., and Lamppa, R. S. 2004. Identification of a possible new anthracnose race on dry beans. (Abstr.) Phytopathology 94:S25.

5. del Rio, L. E., Lamppa, R. S., and Gross, P. L. 2003. Characterization of the reaction of North Dakota dry bean cultivars to three races of Colletotrichum lindemuthianum. Plant Dis. 87:263-265.

6. del Rio, L. E., Lamppa, R. S., Gross, P. L., Brolley, B., and Prischmann, J. 2003. Identification of Colletotrichum lindemuthianum race 73 in Manitoba, Canada. Can. J. Plant Pathol. 25:104-107.

7. Dongfang, Y., Conner, R. L., Yu, K., Balasubramanian, P., Penner, W. C., and Yager, L. M. 2008. Identification of anthracnose resistance genes in dry bean cultivars grown in Manitoba. Can. J. Plant Sci. 88:771-781.

8. Ferreira, J. J., Campa, A., Perez-Vega, E., and Giraldez, R. 2008. Reaction of a bean germplasm collection against five races of Colletotrichum lindemuthianum identified in northern Spain and implications for breeding. Plant Dis. 92:705-708.

9. Flor, H. H. 1947. Host parasite interaction in flax rust-Its genetics and other implications. Phytopathology 45:680-685.

10. Goncalves-Vidigal, M. C., Lacanallo, G. F., and Vidigal, P. S. 2008. A new gene conferring resistance to anthracnose in Andean common bean (Phaseolus vulgaris L.) cultivar 'Jalo Vermelho'. Plant Breed. 127:592-596.

11. Goncalves-Vidigal, M. C., Vidigal, P. S., Medeiros, A. F., and PastorCorrales, M. A. 2009. Common Bean Landrace Jalo Listras Pretas Is the Source of a New Andean Anthracnose Resistance Gene. Crop Sci. 49:133138 .

12. Kelly, J. D., Afanador, L., and Cameron, L. S. 1994. New races of Colletotrichum lindemuthianum in Michigan and implications in dry bean resistance breeding. Plant Dis. 78:892-894.

13. Kelly, J. D., and Vallejo, V. A. 2004. A comprehensive review of the major genes conditioning resistance to anthracnose in common bean. Hortscience 39:1196-1207.
14. Lenné, J. M. 1992. Pages 134-166 in: Colletotrichum: Biology, Pathology and Control. J. A. Bailey and M. J. Jeger, eds. CAB International, Wallingford, UK.

15. Logozzo, G., Donnoli, R., Macaluso, L., Papa, R., Knupffer, H., and Zeuli, P. S. 2007. Analysis of the contribution of Mesoamerican and Andean gene pools to European common bean (Phaseolus vulgaris L.) germplasm and strategies to establish a core collection. Genet. Resour. Crop Evol. 54:17631779 .

16. Mahuku, G. S., and Riascos, J. J. 2004. Virulence and molecular diversity within Colletotrichum lindemuthianum isolates from Andean and Mesoamerican bean varieties and regions. Eur. J. Plant Pathol. 110:253-263.

17. Mathur, R. S., Barnett, H. C., and Lilly, V. G. 1950. Sporulation of Colletotrichum lindemuthianum in culture. Phytopathology 40:104-114.

18. Melotto, M., Balardin, R., and Kelly, J. D. 2000. Host-pathogen interaction and variability of Colletotrichum lindemuthianum. Pages 346-361 In: Colletotrichum Host Specificity, Pathology, and Host-Pathogen Interaction. D. Prusky, S. Freeman, and M. B. Dickman, eds. American Phytopathological Society, St. Paul, MN.

19. Pastor-Corrales, M. A. 1991. Estandarizacion de variedades diferenciales y designacion de razas de Colletotrichum lindemuthianum. (Abstr.) Phytopathology 81:694.

20. Rava, C. A., Molina, J., Kauffmann, M., and Briones, I. 1993. Determinación de razas fisiológicas de Colletotrichum lindemuthianum em Nicaragua. Fitopatologia 8:388-391.

21. Tu, J. C. 1994. Occurrence and characterization of the alpha-Brazil race of bean anthracnose Colletotrichum-lindemuthianum in Ontario. Can. J. Plant Pathol. 16:129-131.

22. Zaumeyer, W. J., and Thomas, H. R. 1957. A monographic study of bean diseases and methods for their control. Pages 5-15 in: U. S. Dep. Agric. Tech. Bull. No. 868, Washington, DC. 